Investigations

\title{
Efficiency of the Insecticide Composition "Abifipr" at Melofagosis of Sheep
}

\author{
Vladimir N. Domatsky, Andrey A. Nikonov, Nataliya I. Beletskaya and Anna N. Siben \\ The All-Russian Scientific and Research Institute of Veterinary Entomology and Arachnology branch of the \\ Federal State Budgetary Scientific Institution, Tyumen Scientific Centre of Siberian Branch of the Russian \\ Academy of Sciences, Tyumen, Russia, 2, Institutskaya St., Tyumen, 625041, Russia
}

Article history

Received: 21-10-2017

Revised: $10-01-2018$

Accepted: 27-03-2018

Corresponding Author:

Vladimir N. Domatsky

All-Russian Scientific and

Research Institute of Veterinary

Entomology and Arachnology,

All-Russian Scientific and

Research Institute of Veterinary

Entomology and Arachnology,

Russia

E-mail: vdomatsky@yandex.ru

\begin{abstract}
The object of research is livestock animals, i.e., sheep (Ovis aries), agents of parasitic diseases of animals (Melophagus ovinus) and drugs used against myiasis of animals. The purpose of the work is to study the possibility of creation of an insecticide composition on the base of fipronil that will be efficient against the sheep ked and to determine its efficiency against Melophagus ovinus. The results, i.e., laboratory experiments to study the efficiency of the insecticide composition abifipr in different concentrations of fipronil, showed that the composition containing $0.5 \%$ fipronil and $0.1 \%$ abamectin is optimal against the imago of the sheep ked. The application of the dose of insecticide composition abifipr $-1 \mathrm{ml}$ per $10 \mathrm{~kg}$ of live weight locally once on the skin along the spinal column - provides $100 \%$ efficiency against Melophagus ovinus.
\end{abstract}

Keywords: Sheep, Melophagus Ovinus, Melophagosis, Fipronil, Abamectin, Insecticide Activity

\section{Introduction}

One of the most important agricultural branches is livestock breeding, the share of which is $55 \%$ of the cost of gross product of the agricultural branch. The branch provides the demands of population of the country with the most important food products, being the main sources of protein of animal origin and also the raw material for various branches of the processing industry (Barbashin, 2009). According to Belostotskii, in recent years in some entities of the Russian Federation, including the Tyumen region, the productive agricultural livestock has been increasing (Belostotskii, 2015). The livestock productivity is influenced not only by the favorable conditions of breeding and appropriate feed but also by the presence of diseases of a different aetiology in farms, among which the diseases caused by insects are not the last. Thus, according to the results of our research, the most widespread type of sheep myiasis is melophagosis, the prevalence of which from 2012 till 2016 was $9.6 \%$ in the average and in some farms it reached $100 \%$.

The high degree of melofagosis occurrence rate in sheep and the lack of efficient remedies used for this disease were the reasons for developing a preparation that would have high insecticidal activity, low toxicity to animals and the minimum effect on the environment. In this respect, the aim of our study was to create a fipronilbased insecticidal composition to be used for sheep melofagosis. For this purpose, tasks were identified, which allowed creating the required form of administration in the process. The tasks of the research included the folowing: choosing the components required for creating a convenient and easy to use form of the preparation, performing laboratory tests on Melophagus ovinus for identifying insecticidal properties of the form of administration, studying efficiency in field experiments on the sheep with melofagosis and studying its toxic effect on animals (physiological and hematological parameters).

Melophagosis (sheep ked) is an invasive disease caused by parasitizing of the stationary ectoparasite Melophagus ovinus on the sheep bodies. The biological peculiarity of keds is that a female insect gives birth to a single, completely developed maggot that fixes on the wool and pupates during $12 \mathrm{~h}$. The puparium of the pupa is impenetrable for insecticides. Pubescent parasites, against which insecticides can be active, appear only in 19-23 days in summer and in 36 days in winter. Female insects live for 4-5 months, giving birth to 10-15 maggots during their lives; male insects live for 80 days. Thus, the infection intensity increases wavily and rather slowly (Radostits et al., 1994). 
According to different authors, outside the host's body keds can survive for 5 days to 3 weeks and can constitute a danger of infection of the livestock. Female and male insects are bloodsuckers; they eat several times per day and therefore, infection with a high intensity can cause severe anemia (Sewell and Brockesby, 1990; Urquhart et al., 1996; Kosminkov et al., 2017).

Melophagus ovinus is widely distributed in the world, except tropics, preferring regions with a moderate climate. The prevalence of sheep ked is increasing in more humid regions of Europe where melophagosis has been registered in more than $30 \%$ of the sheep flocks. Now the prevalence is revealed in the North America and the South America, in some parts of Asia and Africa, Australia and New Zealand, where keds are active during cooler months and are representatives of the parasite fauna of hair sheep more often than fine-wool sheep (Small, 2005; Radostits et al., 1994).

Besides anemia, the main clinical features are itch, scratches, various types of dermatoses - from follicular traumas to diffuse dermatitis and tabescence. The excrements of sheep ked color the wool and decrease its cost. Multiple stings damage sheep skin causing defects; the average day weight gain decreases by 13.4\% (Sewell and Brockesby 1990), wool clip - by $20 \%$ and wool fibers output - by up to 7\% (Getachew, 2015).

According to some researchers, M. ovinus is a vector of infection agents of trypanosomiasis, spirochetosis, rickettsiosis and other diseases (Rakhimov, 1971; Korhonen et al., 2015). The observations emphasized the potential role of Bartonella melophagi as a zoonotic agent. In particular, B. melophagi was revealed in the blood of two patients of hospitals in different parts of the USA and both reported about the frequent contact with domestic animals (Maggi et al., 2009).

The compounds classified among synthetic pyrethroids (for example, cypermethrin, deltamethrin), organophosphorous preparations (for example, diazinon, ethion, phoxim, etc.), carbamates and heterocyclic derivatives are mainly used to fight with insects. Macrocyclic lactones (for example, abamectin, doramectin, ivermectin, moxidectin) are injected. Finished pharma products used for productive animals that contain one compound as an active ingredient usually have a rather narrow spectrum of insecticidal activity, short protection effect and lead to the fast development of resistance to the active ingredient in the population of insects. Inhibitors of insect development (for example, diflubenzuron, triflumuron), used in some countries against lice, are usually inefficient against sheep keds (Junquera, 2015).

The most efficient method of sheep treatment is immersion or complete dipping of sheep into the constant baths or movable tanks with insecticides. The spraying can be as efficient as immersion and can be more technological. Here it is necessary to use treatment means forming the pressure of 7-14 $\mathrm{kg} / \mathrm{cm}^{2}$ for short hair and $21-28 \mathrm{~kg} / \mathrm{cm}^{2}$ for long hair. Now new "spot-on" or "pour-on" forms of pyrethroids are considered to be perspective; they are easy to use and can be used in the winter period as well as insecticide powders. Besides, the treatment using these preparations is more ecologically and economically sound. (are eco-friendly and economic).

According to some authors, for efficient sheep treatment against melophagosis, due to the biological peculiarities of parasite, it is necessary to use the insecticides with the remaining activity $\geq 3-4$ weeks and in the northern regions it should be $\geq 4-5$ weeks; however, now all insecticides used for productive animals do not meet these requirements (Getachew, 2015; Junquera, 2015).

Nevertheless, the use of such preparations will allow performing the single treatment of animals and this will significantly increase the branch profitability. Fipronil, accumulated in hair follicles and sebaceous follicles, possesses the long protective effect and is widely used as an insectoacaricide of external application for non-productive animals (dogs, cats, ferrets), often in combination with other acting substances (Bonneau et al., 2015).

Thus, the preparations widely used in Russia, INSPECTOR TOTAL K and S (Russia) manufactured by RPC ECOPROM, CJSC (Russia), registration No. PVR-3-7.12/02839 and PVR-3-7.12/02838 dd. 06.06.2012, contain fipronil and moxidectin; FINPRIST $^{\circledR}$ COMBO, manufactured by KPKA, pharmaceutical plant, village Novo Mesto, AO (Slovenia), registration No. RK-VP-4-3172-16 dd. 22.07.2016 (for dogs), registration No. RK-VP -4-3173$16 \mathrm{dd}, 22.07 .2016$ (for cats and ferrets) - fipronil and methoprene, etc. and the active ingredient content depends upon the type of animals.

According to the data of researchers, the preparations are safe for dogs and their owners when used correctly, but the veterinary staff can be in danger after everyday contact with insectoacaricides (Nichols et al., 2014).

However, there is an opinion that uncontrolled and large-scale use of fipronil makes a significant harm to the environment, especially to honey bees (Apis mellifera), for whom fipronil is extremely toxic and to earthworms (Lumbricidae) (Van der Sluijs et al., 2015; Chagnon et al., 2015).

The preparation is extremely dangerous for fish and water invertebrates, some birds (for example, gallinaceous birds) but not for the others (for example, ducks); the preparations based upon fipronil are not used for rabbits. Fipronil is not used for productive animals in the USA, the EU, Australia but it is widely used in Mexico and in the countries of Latin America (in 
particular, ECTONIL $®$ POUR ON (SENASA Perú: F.07.03.N.0281 - it is used to treat cattle, sheep, camels, horses, Guinea pigs and poultry). In this case, the safety interval for meat is 3-4 months, for milk animals' treatment fipronil is not used (Junquera, 2015). Based on the above, we chose fipronil as the active substance for creating a medicine for sheep melofagosis.

\section{Materials and Methods}

Experimental work was conducted in 2012-2016 at the laboratory of myiasis of animals of the All-Russian Scientific and Research Institute of Veterinary Entomology and Arachnology and also in the farms of the Tyumen region when the Melophagus ovinus situation was bad. Abifipr is an insecticide composition than contains fipronil and abamectin.

Fipronil [5-amino-[2,6-dichloro-4(trifluoromethyl)phenyl]-4-[(1R,S)(trifluoromethyl)sulfinyl]-1H-pyrasol-3-carbonitrile] is a pesticide chemical active agent (class of phenylpyrazoles) used in agriculture and medical practice, nurse and domestic disinfection for fighting the pest and synanthropic insects and also in veterinary for fighting the mites and fleas. It has a contact, enteral and partially systemic action with long protection effect.

Abamectin (Avermectin B1) is a mixture of 5-Odimetilavermectine A1a (i) and 5-O-dimetil-25-di(1methylpropyl)-25-(1-methylethyl) avermectin Ala (ii) the fermentation product of Streptomyces avermitilis that possesses the parasitocidal activity and is used as an active agent of insectoacaronematocide preparations. It is widely used for all types of agricultural animals and poultry. There are some restrictions for cats and dogs with MDR-1 gene defect, as all preparations of the group of macrocyclic lactones have. In our insecticide composition, we used Abamectin in the concentration of $0.1 \%$ of the active agent.

In the laboratory experiments on studying the efficiency of insecticide composition of Abifipr in different concentrations of fipronil, we used the method of forced contact with imago of sheep keds of natural populations. As the sheep ked is not the official testing object to determine the efficiency of insecticides, we used the estimation methods of activity of pediculicidal agents; in particular, the method of impregnation when estimating the agents designed for fighting with the pediculosis capitis (the agent is Pediculus humanus capitus) (Methods of Laboratory Research and Tests of Medical and Preventive Disinfectants for Estimation of Their Efficiency and Safety: Manual, 2010). About 20 insects were put on the treated wool, placed into the test tube, or 10 insects on the filter paper placed into the Petri dish for $60 \mathrm{~min}$. In the control variant, the insects were put on the clear (untreated) wool samples and filter paper. The filter paper was used as the contact surface. It was impregnated with compositions basing upon 100 $\mathrm{ml} / \mathrm{m}^{2}$ of the preparation, wool slivers were treated with the composition basing upon $1 \mathrm{ml} / 10$ sq. m. In total, 3567 insects of sheep ked imago were used in the experiments. After contact, the insects were transferred to the filter paper and put into the thermostat at a temperature of $(28+/-2)^{\circ} \mathrm{C}$.

About 5 series of concentration with a dissolution pitch 2 were prepared to calculate the efficient doses. The insectoacaricide activity was estimated according to the percent of death of arthropods in the experimental variants in comparison with the control variant. We determined the beginning of the insecticide action and also registered the death in $10,30 \mathrm{~min}$ and in $24,48 \mathrm{~h}$ (acute action) and determined the length of the remaining action. To estimate the efficiency and degree of reliability, we used the established procedure method (Methods of Laboratory Research and Tests of Medical and Preventive Disinfectants for Estimation of Their Efficiency and Safety: Manual, 2010).

The factory testing of the insecticide composition was performed on sheep belonging to JSC Soyuz, Sorokinsky District, the Tyumen region. The groups were selected according to the analogue principle. For tests, the wedders (castrated sheep) at the age of 11-12 months were impulsively infested with melophagosis (n-42). Animals of every group and inside the group were kept separately.

Abifipr, containing $0.5 \%$ of fipronil and $0.1 \%$ of abamectin, was used on sheep once by the method of local application on skin along the spinal column (pouron) based on $0.5 ; 1.0$ and $2.0 \mathrm{ml}$ per $10 \mathrm{~kg}$ of live weight. The result was estimated in 5 days according to the availability or absence of alive keds. After tests, the animals of the control group (6 animals) were treated with the preparation based upon $1.0 \mathrm{ml}$ per $10 \mathrm{~kg}$ of live weight. The study of the insectoacaricide activity of the preparations was performed according to the standard practice (Urquhart et al., 1996). All obtained digital data were processed by the method of variation statistics (Rakhimov, 1971; 1).

\section{Results}

According to the results of our research, the leading type of sheep myiasis is melophagosis, the prevalence of which from 2012 till 2016 was $9.6 \%$ in the average and in some farms it reached $100 \%$. According to the set 
goal, we performed laboratory experiments to study the insecticide activity of the abifipr composition with different concentrations of fipronil. The main data of the acute insecticide activity and the length of the remaining action are shown in Table 1 . The tests showed that the death of keds starts in 15-23 min after contact with surface treated with the preparation; 40-76.67\% of parasites die in $30 \mathrm{~min}$, in a day in all Petri dishes there were no alive keds. In our opinion, the beginning of the insecticide effect is connected mainly to the action of abamectin and the length of the remaining action - with the action of fipronil.

As for fipronil, the efficiency indexes are the following: acute action - death of $70 \%$ insects on the 2 nd day; the length of remaining action is less than 30 days, the compositions No. 3-5 have met completely the requirements to the insecticide activity of the studied compositions. Thus, the laboratory experiments on studying the insecticide activity of abifipr in different concentrations of active agents revealed that the composition containing $0.5 \%$ of fipronil and $0.1 \%$ of abamectin was the optimal variant against the sheep ked imago. The factory (in situ) tests of combined insecticide composition abifipr were performed in vivo on sheep belonging to JSC Soyuz, Sorokinsky District, the Tyumen region.

For tests Abifipr composition No. 3 containing 0.5\% fipronil and $0.1 \%$ abamectin was used. For sheep, the composition was used once locally on the skin along the spinal column (pour-on) based upon 0.5, 1 and 2 $\mathrm{ml}$ per $10 \mathrm{~kg}$ of live weight. The result was recorded in $24 \mathrm{~h}$ and 30 days according to availability or absence of alive keds (Table 2).

The test results showed that application of the preparation abifipr containing $0.5 \%$ of fipronil and $0.1 \%$ of abamectin at a dose of 1 and $2 \mathrm{ml}$ per $10 \mathrm{~kg}$ of live weight once locally on the skin along the spinal column provided $100 \%$ efficiency against Melophagus ovinus. Using this preparation based upon $0.5 \mathrm{ml} / \mathrm{kg}$ of live weight, the extensive efficiency was $77.8 \%$ in a day and only $33.33 \%$ - in 30 days. Thus, we chose the optimal dose of the preparation, that was, $1 \mathrm{ml}$ per 10 $\mathrm{kg}$ of live weight.

Simultaneously with the tests of insecticide activity, we estimated the impact of abifipr on the organism of sheep during one week before the test three times, in a day after treatment and during 10 days after three times. We took into attention the cardiac function, temperature, respiration rate, nervous-reflex excitability, appetite, state of pupils and visible mucous membranes. Besides, we controlled some hematologic (hemoglobin, red blood cell count and white blood cell count, leukogram, bloodsedimentation test) and biochemical values. As a result of clinical observations of tested animals, we have not revealed visible deviations that point to intoxication. The hematologic and biochemical values also varied within the range of physiological norm during the research.

Table 1: Comparative estimation of efficiency of different concentrations of fipronil in insecticide composition against imago of sheep ked

\begin{tabular}{|c|c|c|c|c|c|}
\hline \multirow[b]{2}{*}{ Indices of insecticide effect } & \multicolumn{5}{|l|}{ Fipronil, \% } \\
\hline & $\begin{array}{l}\text { Composition } \\
\text { No. } 1 \\
(0.125)\end{array}$ & $\begin{array}{l}\text { Composition } \\
\text { No. } 2 \\
(0.25)\end{array}$ & $\begin{array}{l}\text { Composition } \\
\text { No. } 3 \\
(0.5)\end{array}$ & $\begin{array}{l}\text { Composition } \\
\text { No. } 4 \\
(1.0)\end{array}$ & $\begin{array}{l}\text { Composition } \\
\text { No. } 5 \\
(2.0)\end{array}$ \\
\hline $\begin{array}{l}\text { Beginning of insecticide effect } \\
\text { in vitro at forced contact, min }\end{array}$ & $16 \pm 0.40$ & $21.0 \pm 0.35$ & $17 \pm 0.40$ & $20.0 \pm 0.66$ & $18.0 \pm 0.52$ \\
\hline Ked imago dead in $30 \mathrm{~min}, \%$ & 40.00 & 53.33 & 70.00 & 76.67 & 66.66 \\
\hline Ked imago dead in $24 \mathrm{~h}, \%$ & 33.33 & 66.67 & 100 & 100 & 100 \\
\hline Ked imago dead in $48 \mathrm{~h}, \%$ & 70.00 & 83.33 & 100 & 100 & 100 \\
\hline $\begin{array}{l}\text { Length of effect in vitro at } \\
\text { forced contact, days }\end{array}$ & 21 & 28 & $35 \pm 0.5$ & $36.5 \pm 0.5$ & $39 \pm 0.5$ \\
\hline
\end{tabular}

Table 2: Comparative estimation of efficiency of different doses of abifipr composition against Melophagus ovinus

\begin{tabular}{llllll}
\hline $\begin{array}{l}\text { Dose, ml per 10 kg } \\
\text { of live weight } \\
\text { efficiency, \% }\end{array}$ & $\begin{array}{l}\text { Number of animals } \\
\text { in experiment }\end{array}$ & $\begin{array}{l}\text { Remained infected } \\
\text { In 24 h }\end{array}$ & 2 & In 30 days & Extensive \\
\hline 0,5 & 9 & - & 6 & 77.8 & In 24 h \\
1,0 & 16 & - & - & 100 & 100 \\
2,0 & 21 & 6 & 6 & - & 100 \\
control & 6 & & & & - \\
\hline
\end{tabular}




\section{Discussion}

As a result of the performed research, we formed an insecticide composition based upon fipronil and abamectin for treatment against Melophagus ovinus. The optimal concentration of fipronil in the insecticide composition was $0.5 \%$ and that of abamectin $-0.1 \%$, which was confirmed during laboratory tests. The combined use of fipronil and other active substances shows high efficiency and low toxicity of the obtained preparations for animals. The results of our research have confirmed safety of using the created preparation in recommended dosages for sheep, which has also been noted in works of many researchers, which indicated low toxicity of fipronil for animals (Arisov et al., 2014; Dryden, 2005; Danilevskaya et al., 2013). In the veterinary practice, the problem of parasites' developing resistance to commonly used insecticides is becoming more and more important. In this regard, the combined use of two active ingredients, fipronil and abamectin, is required for reducing the risk of parasites' developing resistance, which is consistent with the previously published data about the influence of two active ingredients in a preparation on reducing the risk of resistance in populations of pathogens of invasion diseases. It is also a feature of complex products, where each substance is used at lower dosage, but the synergistic effect on the parasite is obtained, which ensures the required efficiency (Danilevskaya et al., 2013). On-the-farm research revealed the high therapeutic effectiveness against the agents of melophagosis and this corresponded to the data of Bonneau et al. (2015) obtained during myiasis of nonproductive animals. Due to the action of fipronil, we could reach the long insecticide effect because of the accumulation of this preparation in the hair follicles and sebaceous glands (Bonneau et al., 2015). This allowed using the insecticide composition once by the "pour-on" method, which decreased the ecological impact on environment due to the toxic character of fipronil for fish, bees, some invertebrates and birds (gallinaceous birds) and also the costs of antiparasitic actions (Junquera, 2015; Van der Sluijs et al., 2015; Chagnon et al., 2015). Cutaneous use of the preparation is convenient and greatly simplifies the process of treating an animal without the use of sophisticated equipment, which allows treating many sheep in a short time.

\section{Conclusion}

The laboratory tests of study of the insecticide activity of the abifipr composition in different concentrations of fipronil showed that the composition containing $0.5 \%$ of fipronil and $0.1 \%$ of abamectin was optimal against the sheep ked imago. The application of abifipr composition containing $0.5 \%$ of fipronil and $0.1 \%$ of abamectin based upon the dose of 1 and $2 \mathrm{~mL}$ per $10 \mathrm{~kg}$ of live weight once locally on the skin along the spinal column provides $100 \%$ efficiency against Melophagus ovinus. As a result of clinical observations of tested animals, we have not revealed visible deviations that point to intoxication. The hematologic and biochemical values obtained during the research also varied within the range of the physiological norm.

Thus, we determined the possibility of use of the insecticide composition containing fipronil for the treatment against sheep Melophagus ovinus, which was the evidence of the fact that the goals and tasks of the research had been reached. However, the insecticidal and acaricidal effect of the preparation on other types of parasites in various animals should be studied further. Regarding the ecological risk of pollution of the environment, during the application of the preparation by the "pour-on" method in the recommended dose $(1 \mathrm{ml} / 10$ $\mathrm{kg}$ of live weight once) it is significantly lower than when applying the preparation by the spraying method, bathing and is not comparable with the risk connected to the use of fipronil as a pesticide in the agrochemistry.

\section{Acknowledgement}

We thank our Institute for supporting our work.

\section{Author's Contributions}

All authors participated in all experiments, coordinated the data-analysis and contributed to the writing of the manuscript.

\section{Ethics}

This article is original and contains unpublished material. The corresponding author confirms that all of the other authors have read and approved the manuscript and there are no ethical issues involved.

\section{References}

Arisov, M.V., V.A. Stepanov and E.S. Smirnova, 2014. Farmako-toksikologicheskaya otsenka kompleksnogo protivoparazitarnogo preparata dlya sobak i koshek [Pharmaco-toxicological assessment of a comprehensive anti-parasitic preparation for dogs and cats]. Russian Vet. J. Small Domestic Wild Ani., 4: 36-39.

Barbashin, A.I., 2009. Ekonomika Selskogo Khozyaistva [Agricultural Economy]. 1st Edn., KSAA, Kursk, pp: 278.

Belostotskii, A.A., 2015. Ustoichivost razvitiya otrasli zhivotnovodstva [Sustainable growth of the cattlebreeding branch]. Voprosy Ekonomiki Prava, 88: 108-111. 
Bonneau, S., J. Fourie, C. Navarro and M. Francm, 2015. Efficacy of a new combination of fipronil and permethrin (effitix ${ }^{\circledR} \quad$ spot-on) against flea infestations in dogs. Proceedings of the 25th International Conference of the World Association for the Advancement of Veterinary Parasitology, (AVP'15), Liverpool.

Chagnon, M., D. Kreutzweiser, E. Mitchell, C.A. Morrissey and D.A. Noome et al., 2015. Risks Of Large-Scale Use Of Systemic Insecticides To Ecosystem Functioning And Services. Environ. Sci. Pollut. Res., 22: 119-134. DOI: 10.1007/s11356-014-3277-x

Danilevskaya, N. V., A.A. Deltsov and M.I. Kuznetsova, 2013. Vliyanie insektoakaritsidnih preparatov na osnove fipronila i moksidektina na laboratornih i melkih domashnih zhivotnih [The influence of fipronil-based insect-acaricidal preparations and moxidectin on laboratory and small animals]. Russian Vet. J. Small Domestic Wild Ani., 2: 8-12.

Dryden, M.W., 2005. Comparative speed of kill of selamectin, imidacloprid and fipronil-(S)methoprene spot-on formulations against fleas on cats. Vet. Ther., 6: 228-236.

Getachew, K., 2015. Experimental study on sheep infested with bovicola ovis and melophagus ovinus of pathological changes, processed skin defect and effect of treatment in improving skin quality. MSc Thesis of Tropical Veterinary Pathology, College of Veterinary Medicine and Agriculture of Addis Ababa University, Bishoftu, Ethiopia.

Junquera, P., 2015. Ectoparasiticides and anthelmintics used in production animals, dogs and cats in spanish-speaking latin America and Spain. A market survey. Proceedings of the 25th WAAVP International Conference, Aug. 16-20, Parasitipedia.Net, Liverpool.

Korhonen, E.M., C. Pérez Vera, A.T. Pulliainen, T. Sironen and K. Aaltonen et al., 2015. Molecular detection of bartonella spp. in deer ked pupae, adult keds and moose blood in Finland. Epidemiol. Infect., 143: 578-585. DOI: $10.1017 / \mathrm{S} 0950268814001411$

Kosminkov, N.E., B.K. Laipanov, V.N. Domatsky and V.V. Belimenko, 2017. Parazitologiya i Invazionnie Bolezni Zhivotnykh [Parasitology and Invasion Diseases in Animals]. 1st Edn., "INFRA-M", Moscow, pp: 467

Maggi, R.G., M. Kosoy, M. Mintzer and E.B. Breitschwerdt, 2009. Isolation of Candidatus Bartonella melophagi from Human Blood. Emerg. Infect. Dis., 15: 66-68.

DOI: $10.3201 /$ eid 1501.081080
Methods of Laboratory Research and Tests of Medical and Preventive Disinfectants for Estimation of Their Efficiency and Safety: Manual, 2010. Metody laboratornykh issledovanii i ispytanii mediko-profilakticheskikh dezinfektsionnykh sredstv dlya otsenki ikh effektivnosti i bezopasnosti: Rukovodstvo. 1st Edn., Federal Centre of Hygiene and Epidemiology of Rospotrebnadzor, Moscow, pp: 615.

Nichols, H., R.C. Gupta, R.B. Doss, S.D. Bland and T.D. Canerdy et al., 2014. Residue of fipronil, smethoprene and amitraz in dog blood and in gloves from topical certifect ${ }^{\circledR}$ application: Toxicity and safety considerations. Jacobs J. Vet. Sci. Res., 1: 1-9.

Radostits, O.M., D.C. Blood and C.C. Gay, 1994. Veterinary Medicine : A Textbook of the Diseases of Cattle, Sheep, Pigs, Goats and Horses. 8th Edn., Baillière Tindall, London, ISBN-10: 070201592X, pp: 1763.

Rakhimov, T.K., 1971. Ovechii Runets Melophagus Ovinus Kak Perenoschik Anaplasma Ovis [Melophagus Ovinus as Vector of Anaplasma Ovis]. In: Bolezni Selskokhozyaistvennykh Zhivotnykh [Diseases of Livestock Animals], Rakhimov, T.K. (Ed.), Tashkent, pp: 42-43.

Sewell, M.M.H. and D.W. Brockesby, 1990. Hand Book on Animal Disease in the Tropics. 4th Edn., Bailliere Tindall, pp: 28.

Small, R.W., 2005. A review of melophagus ovinus (L.), the sheep ked. Vet. Parasitol., 130: 141-155.

Urquhart, G.M., J. Armour, J.L. Duncan, A.M. Dunn and F.W. Jennings, 1996. Veterinary Parasitology. 5th Edn., Longman Scientific and Technical.

Van der Sluijs, J.P., V. Amaral-Rogers, L.P. Belzunces, M.F.I.J. Bijleveld van Lexmond and J.M. Bonmatin et al., 2015. Conclusions of the worldwide integrated assessment on the risks of neonicotinoids and fipronil to biodiversity and ecosystem functioning. Environ. Sci. Pollut. Res., 22: $148-154$. 